\title{
Comments
}

\section{RECENT DEVELOPMENTS IN THE NO-SALE THEORY UNDER THE SECURITIES ACT OF 1933: PROPOSED REVISION OF RULE 133}

On September 15, 1958 the Securities and Exchange Commission announced a proposed revision of Rule 133 of the Securities Act of $1933^{1}$ which, if finally adopted, will work a substantial change in the operation of the widely discussed no-sale theory. ${ }^{2}$ The general effect of the proposed revision would be to delineate, more particularly, the circumstances under which a recipient of securities issued pursuant to a merger, consolidation, reclassification, or sale of assets for stock would, upon his resale of the securities, be subject to the registration and prospectus requirements of the Securities Act. It is the purpose of this comment to examine both recent developments in the administration of the no-sale rule and the consequences of adoption of Proposed Rule 133. Since full understanding of the problem is dependent upon comprehension of the present Rule 133, the rationale and historical development of the no-sale theory will first be considered.

\section{The rule in context}

\section{DeVelopment of the No-Sale T'heory}

Section 5 of the Securities Act declares unlawful the use of any means or instruments of interstate commerce or of the mails to sell a security for value ${ }^{3}$ unless a registration statement relating to the security is in effect. The section then declares unlawful the use of any instruments of interstate commerce or of the mails to transmit a prospectus concerning a registered security unless the prospectus requirements of the Act are met. ${ }^{4}$

The no-sale rule is an interpretation of when a sale lias occurred. Essentially it provides that, for purposes only of section 5, no sale transaction shall be deemed to be involved so far as the sharelolders of a corporation are concerned when there is an exchange or modification of their securities pursuant to

148 Stat. 74 (1933), 15 U.S.C. $\$ \$ 77 a-77 a a(1952)$. In both text and footnotes the Sccuritics Act of 1933 is hereafter referred to as "Securities Act" or "Act." Rule 133 is found at 17 C.F.R. 8230.133 (Supp. 1958), and the text of the proposed revision to Rule 133 is reproduced in Securities Act Release No. 3965, CCH Fed. SEc. L. REp. III 76, 609, 4133-2 (1958).

2 Although Rule 133 was accorded slight comment until lately, it has been the subject of a number of recent studies. See Purcell, A Consideration of the No-Sale Theory Under the Securities Act of 1933, 24 Brookryn L. REv. 254 (1958) (hereafter cited as Purcell, 24 BrookLYN L. Rev.) ; Orrick, Registration Problems Under the Federal Securities Act-Resales Following Rule 133 and Exchange Transactions, 10 Hastrngs L,J. 1 (1958) (hercafter cited as Orrick, 10 Hastings L.J.) ; Throop, In Defense of Rule 133-A Case For Administrative Self-Restraint, 13 Bus. Law. 389 (1958); Sargent, A Review of the "No-Sale" Theory of Rule 133, 13 Bus. LAw. 78 (1957) (hereafter cited as Sargent, 13 Bus. Law.); Note, 67 HaRv. L. Rev. 1237 (1954); and see Loss, Securities Regulation 259, 334-40, 364, 393-94 (1951, Supp. 1955).

For related discussion, see Cowett, Reorganizations, Consolidations, Mergers, and Related Corporate Events Under the Blue Sky Laws, 13 Bus. Law. 418 (1958); Demmler, Developments in Federal Regulation of Securities, 12 Bus. Law. 470, 474 (1957); Modesitt, Secondary Distribution of Securities, 34 DICTA 156, 166 (1957); Darrell, The Use of Reorganization Techniques in Corporate Acquisitions, 70 HARv. L. Rev. 1183, 1189 (1957); Fuld, Some Practical Aspects of a Merger, 60 HARv. L. REv. 1092, 1111-1112 (1947).

3 The term "sale," "sell," "offer to sell," or "offer for sale" is defined at 48 Stat. 74 (1933), 15 U.S.C. $\$ 77 \mathrm{~b}(3)$ (1952).

448 STaT. 74 (1933), 15 U.S.C. 877 (e) (1952). 
a reclassification, merger, consolidation, or sale of assets in exchange for stock of another corporation, if (a) the vote of a majority of stockholders is required by the law of the state of incorporation or by the corporation's articles of incorporation to approve the transaction, and (b) sucl vote, when obtained, will bind all shareholders of the corporation whose shareholders are voting except for the statutory appraisal rights of dissenters. In jargon, there must be a "cram down" effectuated by "corporate action." The effect of Rule 133 is to exempt securities issued under its aegis from registration under section 5 , and, consequently, from the prospectus requirements of section 10 of the Act. ${ }^{5}$

\section{The theory}

The theoretical rationale of the no-sale rule is based on the assumption that the transactions whicl accomplish a reorganization embraced by Rule 133 occur solely by operation of law througl the exercise by stockholders of their franchise to vote as members of a corporate body. The exercise of voting rights by shareholders, acting as a class to exchange or to alter their securities, is considered a distinctly different transaction from that of choosing, as an individual, to accept or to reject a security offered in exchange for another security. In Rule 133 transactions it is considered that the exchange occurs because of the corporate action authorized by a specified majority of the interests affected rather than because of the individual shareholder's consent. Therefore, the theory concludes, the prime element of a contract of sale, unutual assent between the corporation and the individual stockholders, is lacking. ${ }^{6}$

Despite the logical neatness of this rationale, there is reason to suspect that the

5 Provisions of the Securities Act itself, other statutes, and administrative and judicial glosses have limited the application of Rule 133. These himitations are discussed in detail in text starting at note 25 infra.

It is to be noted that when a security is listed on a national exchange, the proxy regulations of the Securities Exchange Act of 1934, 48 Stat. 881, 895 (1934), 15 U.S.C. \$\$ 78a-78u (1952) (hereafter cited as Exchange Act), are applicable even though Rule 133 has exempted the security from the registration and prospectus requirements of the Securities Act. Such proxy statements would have to include the details of the suggested merger, the basis for calculating the exchange ratio of the shares, the persons who did the calculating and their interest in the merger, names of the promoters and their interest, and the reasons in favor of the merger. Schedule 14A, 17 C.F.R. § 240, 14a-11 (Supp. 1958).

6 The SEC outlined this theoretical basis in a brief submitted as amicus curiae in National Supply Co. v. Leland Stanford Jumior University, 134 F.2d 689 (9th Cir. 1943), cert. denied, 320 U.S. 773 (1943). In this case Stanford University, as a stockholder of one of two corporations involved in a merger, sought recovery from the successor corporation on the grounds that proxy solicitation material was misleading and terms of consolidation were unfair, also alleging that the Securities Act had been violated by failure to register the stock of the consolidated company. The Commission's brief in support of the no-sale theory stated:

But consolidations such as the one involved in this case and mergers under related provisions of law are not comparable to the various exchange situations just discussed. In such consolidations, and mergers the alteration of the stockholder's security occurs not because he consents to an exchange, but because the corporation by authorized corporate action converts his security from one form to another. That is to say, ... there is no sale where (1) the role of the stockholders is effective (subject to director's action and other statutory requirements) as corporate action and (2) this action binds all stockholders, assenters, dissenters, and non-voters alike (subject only to appraisal rights of dissenters) ... in such cases a proposed corporate act is submitted to stockholders to be accepted or rejected by them as a class, in their capacity as nembers of the corporate body. Even though the stockholders may participate in the vote which results in changing his rights as a stockholder, lis action in so doing is the action of a member of the corporation exercising his franchise, rather than the action of a security-loolder choosing to accept an offer of exchange made to him as an imdividual; and obversely, 
no-sale theory is more an attempt to defend an administrative rule of convenience than an eternal truth of corporate law. Support for: this conclusion seems indicated by the Cominission's refusal to apply the no-sale logic beyond the scope of section 5. Accordingly, it expressly has been ruled that the theory is not applicable when defining "sale" under the anti-fraud provisions of the Securities Act or the Securities Exchange Act of $1934 .{ }^{7}$ Nor has the Commission applied the no-sale rule to the issuance and sale of securities in reorganization transactions under the Public Utility Holding Company Act of $1935,{ }^{8}$ the Investment Company Act of 1940, and the Securities Exchange Act of $1934 . .^{10}$ And, although there has been no ruling, it appears that the theory will not be embossed upon the definition of "sale" as used in section 302(2) of the Trust Indenture Act. ${ }^{11}$

It appears that the SEC's varying interpretations are best harmonized if "sale" is considered a flexible term to be interpreted so as to effect the intent of the particular statute in which it appears. ${ }^{12}$ In fact, the Commission has consistently justi-

the solicitation of his vote is nothing more than a request for the exercise of his fran-

chise as a member of the corporation, not an offer of exchange or sale of new securitics

to him as an individual.

Despite this elaborate attempt to have the Commission's theory considered and approved, the court based a holding in favor of National Supply on the issue of whether the solicitation material was, in fact, misleading. Referring to the SEC's brief, the court said: "Without going into the matter, we may say that we are in accord with the views of the Commission." 134 F.2d at 694 (1943). There has been no further judicial test of the soundness of the theory.

7 Securities Act Release No. 3420, CCH FEd. SEc. L. REp. I 2128.01 (1951).

8 Holding Company Act Release No. 6340, CCH Fen. Sec. L. REp. \2128.01 (1945).

${ }^{9}$ In the Matter of E. I. DuPont de Neinours and Company, 34 S.E.C. 531 (1953), the Commission held that the transaction in issue involved a "sale" and a "purchase" for the pur pose of $\$ 17$ of the Investment Company Act, even though a different result might have been reached if the no-sale theory had been followed. This decision reversed in the Matter of Phoenix Securities Corp., 9 S.E.C. 241 (1941), which had considered the no-sale theory applicable to a merger under $\$ 17$. That the Commission does not consider the no-sale thcory a logical necessity in construing "sale" seems indicated by its statement that, "continuing experience under the Investment Company Act has demonstrated that application of the no-sale theory to Section 17 of that Act tends to defeat the legislative purpose of that secion." 34 S.E.C. at 534 (1953).

10 For purposes of defining "purchase" and "sale" the Commission has not applied the no-sale theory to cases involving insider trading provisions of $\S 16$ of the Exchange Act. Rather, the courts have arrived at a definition of these terms in relation to corporate reorganizations by consideration of the legislative objectives and the practical conscquences of a particular interpretation as applied to the transactions before them. See Roberts v. Eaton, 212 F.2d 82 (2d Cir. 1954); Blau v. Hodgkinson, 100 F. Supp. 361 (S.D.N.Y. 1951); Riger, Book Review, 52 Colum. L. Rev. 547, 549-550 (1952). Cf. Ferraiolo v. Newman, 259 F.2d 342 (6th Cir. 1958), cert. deried, 27 U.S.L. WeEK 3244 (U.S. Mar. 3, 1959).

11 Sce Loss, Securtties Regulations 155 (Supp. 1955) ; Throop, In Defense of Rule 133A Case For Administrative Self-Restraint, 13 Bus. Law. 389, 401 (1958); Note, 67 Harv. L. REv. 1237, 1247 (1954).

${ }^{12}$ The statutory concept of "sale" and "offer" in the Securities Act is broader than the commercial meaning of the words. See Securities Act Release No. 3965, CCH FEd. SEc. L. REP. $\pi 76,609$ (1958). Congress clearly indicated that it sought to express itself in a broad unanner by making the statutory definition of "sale" inclusive of every contract of sale or disposition of a security for value and every attempt to dispose of a security for value. See H.R. REP. No. 85, 73d Cong., 1st Sess. 11 (1933).

It is interesting to note that under the California Securities Law, which is also designed to protect the public from fraudulent and misleading distributions of securities, a sale is defined by CAL. CORP. CODE $\S 25009$ (a), in part, as ". . . any change in the rights, preferenees, privileges, or restrictions on outstanding securities." This is interpreted to cover mergers, consolidations, and voluntary recapitalizations. See Jennings, The Role of the States in Corporate Regulation and Investor Protection, 23 LAW \& Conteasp. ProB. 193, 213 (1958); Orschel, Administrative Protection for Shareliolders in Califortia Recapitalizations, 4 STAN. L. REv. 215 (1952); Dahlquist, Regulation and Civil Liability Under the California Securities Act: II 34 CAIIE. L. REv. 344, 358 (1946). 
fied the vagaries of construction noted above on the basis that to rule otherwise would be contrary to statutory intent. ${ }^{13}$ Accordingly, it is felt that the most helpful analysis of the no-sale theory is based on an inquiry as to its validity as an interpretation of the Securities Act. But, if it were necessary to attack the theoretical basis of the no-sale rule, ${ }^{14}$ it appears that a strong argument can be made that Rule 133 transactions do involve sales. Statutory reorganizations are dependent upon some measure of individual consent of the shareholders, ${ }^{15}$ and although individual volition plays a lesser part in these transactions than in a common law sale or contract, the element of shareholder consent appears strong enough to negate any conclusion that Rule 133 transactions occur solely by operation of law. In accord with this approach, the SEC has now rejected its own theoretical rationale of the no-sale rule. The Commission's staff, when recommending the proposed revision to Rule 133, stated as a supporting conclusion:

[T]he transactions described in Rule 133 do not, as is often said, occur solely by operation of law and without the element of individual consent by security holders, but on the contrary are basically contractual in their foundation, reflecting essentially contractual relationships among security holders and corporations.16

\section{The no-sale theory as an interpretation of "sale"}

Assuming that Rule 133 does not represent an inexorable rule of law, it is still necessary to consider whether it is a correct interpretation of "sale."17 Validity of interpretative rules turns upon correct interpretation of the law being construed, ${ }_{1}^{18}$ and strong arguments have been made that Rule 133 is an improper construction of the Securities Act. ${ }^{19}$ The general line of attack contends that the no-sale theory is in direct conflict with both specific provisions and general purposes of the Act.

Specifically, it is argued that section 3(a) (9) exempts a reclassification of shares only when no solicitation commission is paid, while Rule 133 operates to exempt reclassifications even though such a commission is paid. It is also pointed out that section $3(\mathrm{a})(10)$ exempts securities issued in court or administratively supervised reorganizations, while Rule 133 exempts securities issued in reorganiza-

13 See, e.g., In the Matter of E. I. DuPont de Nemours and Company, 34 S.E.C. 531, 534 (1953).

14 For a defense of the no-sale theory as a rule of corporate law, see Throop, In Defense of Rule 133-A Case For Administrative Self-Restraint, 13 Bus. LAw. 389 (1958).

15 Nearly all states today require a vote of shareholders before a corporate reorganization can be effected. See Lattin, Afinority and Dissenting Shareholders Rights in Fundamental Changes, 23 Law \& Contems. Prob. 307 (1958); Ballantine, Corporations 685 (rev.ed. 1946). $I(2)]$.

16 Securities Act Release No. 3965, CCH Fed. Sec. L. Rep. 『76,609 (1958) [Conclusion

17 Section 19(a) of the Securities Act delegates to the Commission authority "to inake, amend, and rescind such rules and regulations as may be necessary to carry out the provisions of this title." The same subsection also delegates authority to make, amend, and rescind "rules and regulations governing registration statements and prospectuses for various classes of securities and issuers, and defining accounting, technical, and trade names used in this title." Interpreting "sale," in the context of the Act, to exclude corporate reorganizations appears to be an exercise of the Commission's authority to make rules necessary to carry out provisions of the Act. If we dichotomize administrative rules into legislative rules-the product of the power to create new law - and interpretative rules - the product of interpretation of previously existing law [Davis, Admmistrative Law 194 (1951)]-Rule 133 appears properly classified as an interpretative rule.

18 See Addison v. Holly Hill Fruit Prods., Inc., 322 U.S. 607 (1944).

19 See, e.g., Loss, Securities Regulation 336-37 (1951) ; Sargent, 13 Bus. Law. 78, 83 (1957) ; Note, 67 HARv. L. REv. 1237, 1241-43 (1954). 
tions even though there is no such supervision. ${ }^{20} \mathrm{Jt}$ is contended that the general purposes of the Act are contravened in that the Securities Act's registration and prospectus procedures were established to provide the public with a fair disclosure of the facts essential to an appraisal of a security ${ }^{21}$ while the no-sale rule has allowed a great number of securities to be sold to the public without compliance with the safeguards established by the Act.

On the other hand, persuasive arguments have been advanced to support a thesis that the context of the Securities Act does not contemplate making the registration and prospectus requirements applicable to corporate reorganizations. First, it has been noted that the Act requires filing of a registration statement by the issuer of the securities being offered prior to any solicitation. In the case of a consolidation, the "issuer" is not in existence until all meetings have been lield and the certificate of consolidation is filed. Thus, without anendment of the Act registration by the issuer is logically impossible, while registration after consolidation would be worthless.

Secondly, since the liability provisions of sections 11 and 12 of the Act establish iability of the issuer for damages in favor of both original and subsequent purchasers if there are material misrepresentations or omissions in the registration statement, the problem of which shareholders can utilize the statutory recovery provisions agaimst a registerimg new or surviving corporation appears quite confused. Whether the shareholders of both the new and old corporation could bring suit, whether the shareholders voting in favor of the reorganization would be eligible plaintiffs, and whether shareholders who lave exercised their statutory appraisal rights could still recover are among the more perplexing questions. ${ }^{22}$

Although it probably would be possible to establish procedures obviating these problems, it appears that there are major inconsistencies in considering Rule 133 transactions to be subject to the registration and prospectus requirements of the Act. Perhaps persuaded by these difficulties, the SEC staff recently concluded that due to the nature, purposes, and operation of the Act, the present no-sale rule represents a correct interpretation of "sale." ${ }^{23}$ However, as discussed below, the

20 It often has been noted that Congress has expressed itself in a manner which indicates that mergers or consohidations effectuated by non-judicially supervised procedures shall be covered by the statute. See, e.g., Loss, Securitres Regulation 337 (1951). Specifically, a House report stated:

Reorganizations carried out without such judicial supervision possess all the dangers implicit in the issuance of new securities and are, therefore, not exempt froun the act. For the same reason the provision is not broad enough to include inergers or consohidations of corporations entered into without judicial supervision. H.R. Rep. No. 85, 73d Cong., 1st Sess. 16 (1933).

And see H.R. REP. No. 152, 73d Cong., 1st Sess. 25 (1933).

21 See MCCorancK, UNDERSTANDING THE SECURITIES ACT aNd the SEC 28 (1948).

22 For a more complete exposition of these arguments, see Throop, In Defense of Rulle 133A Case for Administrative Self-Restraint, 13 Bus. Law 389, 395-99 (1958) ; Purcell, 24 BrooKIYN L. REv. 254, 282-87 (1958).

23 The SEC staff concludes on the issue:

We believe, having regard to the nature, purposes and operation of the procedural provisions of sections 4 and 5 , the civil habilities for failure to comply with such procedures, and the operation of certain of the statutory exemptions from section 5 , that Rule 133 represents a reasonable interpretation of the Act on the application of section 5, one that is not inconsistent with the broad purposes of the Act as derived from its structure and history, and a proper exercise of the Commission's defining and rulemaking powers, thereunder, particularly where, as here, this result reflects a consistent interpretation over a period of almost twenty-four years.

Securities Act Release No. 3965, CCH FED. SEC. L. REP. I 76,609 (1958). 
SEC now proposes to exercise its interpretative authority ${ }^{24}$ to define the scope of the no-sale exemption in an attempt to avoid use of Rule 133 as a method of effecting public distributions without meeting the registration and prospectus requirements of the Act.

\section{The shaping of the no-sale theory}

The no-sale rule has been shaped by exercise of both the rule making and the judicial functions of the SEC. The actual terms of the rule have been altered since its initial adoption, ${ }^{25}$ and the operation of the rule has been refined by a series of interpretative glosses, understanding of which is essential to comprehension of the rule as it exists today. These glosses, which will remain effective whether or not Proposed Rule 133 is adopted, will next be considered.

In accord with the rationale of the no-sale theory the Commission has found

24 In an announcement made October 2, 1956 that the Commision was considering reversing the no-sale rule, the SEC asked for views and comments of interested persons. Securities Act Release No. 3698, CCH FED. SEc. L. REp. If 76,409 (1956). Apparently much of the argument submitted centered about alleged inability of the Commission to change an interpretative rule of such long standing. That Congress was specifically made aware of the problem in 1941 [see 3 Hearings before the Committee on Interstate and Foreign Comnterce on H.R. 4344, 5065, 5832, 77th Cong., 1st Sess. 845 (1941) ], at the time of the amicus curiae brief in National Sucpply Co. $v$ Leland Stanford Junior University, see note 6 supra, was also widely relied upon as a bar to SEC action reversing the rule. Chairnan Armstrong went to lengths to disparage such attack:

It seemed to us unfortunate that so much emphasis both at the bearing before the

Commission on January $19,195 \%$, and in many written comments on the proposal, was placed on the proposition that because the "no-sale" rule liad been in existence in one form or another for so long, it must not be changed, and indeed, as some argued that the Commission lacked power to change it. This overlooks the fact that courts from time to time change their interpretation of the statutes in the higlt of new considerations and changing conditions, especially when it appears that the earlier interpretation may not have been in keeping with the original intent of Congress.

Securities Act Release No. 3762, CCH FED. SEc. L. REP. \ 76,511 (1957).

25 The question of whether a corporate reorganization involves a sale of securities under $\$ 2(3)$ of the Act first arose in 1934, at a time when the Federal Trade Commission was administering the Act. The FTC took the position that a "sale" within the meaning of $\S 5$ was involved. See Purcell, 24 BrookLYN L. REv. 254, 257 (1958).

Shortly after the SEC assumed administration of the Act in 1934, the Commission reversed this interpretation and ruled that a merger did not involve a sale and therefore registration under the Act was not required. See Securities Act Release No. 3762, CCH FEd. SEc. L. Rep. 【 76,511 (1957). Substantially this rule was first promulgated in September, 1935 as a note to Form E-1, the then current form for registration of securities sold in the course of a reorganization under the Act. The note excepted from the operation of $\$ 5$ securities issued pursuant to a transfer of assets for stock, a statutory merger, or a consolidation. The applicability of the rule depended upon submission of the reorganization plan to the stockholders receiving the new stock, the efficacy of such vote to effectuate the reorganization, and the power of such vote to bind all stockholders except for dissenters' appraisal rights. This rule was continued in Form E-1 until 1947, wben, as part of a program to simplify administrative forms, E-1 was rescinded. The substitute form omitted the no-sale rule, but the rule was followed administratively until 1951, when Rule 133 was officially promulgated.

As promulgated the rule was broader linguistically than the note to Form E-1 since it covered reclassifications; however, this did not work a substantive change since the theory from its inception had been applied to reclassifications or split-ups effected by the type of vote referred to in Rule 133. Loss, SecuritIEs Regulation 335 (1951). In October 1954, in an apparent attempt to harmonize the no-sale rule with the corporate reorganization sections of the Internal Revenue Code, Rule 133 was amended to include cases involving reorganizations under INr. Rev. Code of 1954 §368(a) (1) (C). Securities Act Release No. 3522, CCH Fed. SEC. L. Rep. 【 76,314 (1954). 
Rule 133 inapplicable when individual shareholder action has been present. When a corporation offers to exchange securities with its shareholders individually, each one having the power to accept or reject, the no-sale rule will not apply ${ }^{23}$ Nor will the rule have any effect when the applicable state law or charter provisions require a unanimous vote of the shareholders to effectuate the proposed corporate adjustment. ${ }^{27}$ Likewise, the rule is not applied when the stockholder, though required to give up his old security, is given a choice of two new securities. ${ }^{28}$ The rule is also inapplicable when bondholders vote to change their securities under an indenture that allows the vote of a certain percentage to bind the class. Here the dissenter is coerced, but the class action is not considered "corporate," the bondholders being creditors and not owners of equity stock. ${ }^{29}$

The no-sale theory has been applied to Massachusetts trusts and other entities substantially comparable to corporations. If the theory is otherwise applicable, it appears that it will be applied when shareholders hold their stock indirectly through voting trust certificates or certificates of deposit. It is immaterial, if the theory otherwise pertains, whether the company whose securities are to be issued is already in existence or not; whether, if it is, the plan or agreement or proposal is submitted with its authority; or whether in the case of a transfer of assets, the securities are to be issued to the shareholders directly or are to be distributed to them as a liquidating dividend or otherwise. ${ }^{20}$

These administrative interpretations, when combined with the Commission's refusal, noted above, ${ }^{31}$ to apply the no-sale theory to the other statutes which it administers, would appear, on balance, to give Rule 133 a narrow scope. Yet the rule has permitted, according to Professor Louis Loss, "the offering of literally billions of securities without registration." 32 Relying on belief that recipients of stock received in a Rule 133 transaction can resell without registration under the exemption of section 4(1) of the Act for "transactions by any person other than an issuer, underwriter, or dealer," the merger and acquisition techniques have become major methods of issuing securities without following the procedures required by section 5.33 This process, known in broker jargon as "freeing up front end stock by merger or consolidation," ${ }^{34}$ created such concern on the part of the Commission

26 See brief for SEC as amicus curiae, p. 9, National Supply Co. v. Leland Stanford Junior University, 134 F.2d 689 (9th Cir. 1943).

27 LOSS, SECURTTIES REguLATTONS 336 (1951).

$28 \mathrm{Ibid}$. However, the rule has been applied when the stockholder has a right of appraisal, although there is a free choice between cash and new securitics. The rationale proffered by the SEC is that in this case there is no option for the dissenter to retain his old shares. Brief for SEC as amicus curiae, p. 13, National Supply Co. v. Leland Stanford Junior University, 134 F.2d 689 (9th Cir. 1943). This rationale, however, appears equally applicable to the choice of two securities.

29 Loss, Securrtes Regulation 336 (1951). This ruling has been criticized on the basis that although bondholders do not technically represent an ownership interest, their action in voting on corporate affairs would seem to constitute "corporate action" as much as a vote of shareholders. 67 HaRv. L. REv. 1237 (1954).

30 Loss, Securties Regulation 335-36 (1951).

31 See text starting at note 7 supra.

32 Loss, Securtties Regulation 336 (1951). See 3 Hearings before House Committee on Interstate and Foreign Commerce on H.R. 4344, 5065, 5832, 77th Cong., 1st Sess. 845 (1941). In March, 1957, the SEC estimated that nearly $\$ 100,000,000$ worth of securitics had been distributed to the public in contrived no-sale transactions-all at great eventual loss to the purchasers. Securities Act Release No. 3762, CCH FED. SEC. L. FEP. II 76,511 (1957).

33 Orrick, Registration Problems Under the Federal Securities Act-Resales Following Rule 133 and Exchange Transactions, 10 Hastongs L.J. 1, 2-3 (1958).

34 See Modesitt, Secondary Distributions of Securities, 34 Dicra 156 (1957). 
that on October 2, 1956 the SEC gave notice that it was considering a complete reversal of the no-sale rule. ${ }^{35}$ Although the SEC later withdrew this proposal, ${ }^{36}$ it continued to study the problem, and the proposed revision to Rule 133 is the product of that study. But, before turning to consideration of the terms of Proposed Rule 133 it is necessary to consider the effect of recent court and SEC decisions on the operation of the present rule.

SEC v. Micro-Moisture Controls, Inc., ${ }^{37}$ involved an allegedly unlawful distribution of unregistered Micro-Moisture Controls stock. This stock had been issued in exchange for the assets of a company known as Converters Acceptance Corporation, of Montreal, Canada. Upon acquisition, Converters Acceptance was dissolved and its Micro-Moisture Controls holdings were distributed prorata among its shareholders-including persons in control of Micro-Moisture Controls and their privies. ${ }^{38} \mathrm{~A}$ public secondary distribution of these securities was then attempted, and the SEC brought proceedings to enjom the public sale. In rejecting any defense based on Rule 133 the court stated:

Rule 133 has no application to the facts here presented for the reason that the shareholders of Converters Acceptance were and are in control of Micro-Moisture and that the "exchange" of Converter's assets for Micro-Moisture stock was but a step in the major activity of selling the stock. The evidence establishes that the persons offering for sale and selling this stock are persons in control of the issuer within the statutory definition of Sec. 2(11) of the Securities Act of 1933. The defendants were in control because they possessed and exercised the power to direct the management and policies of Micro-Moisture (Rule 405) ....39

It has been stated that while the decision itself adds nothing to the no-sale theory, it may have cleared up confusion as to the effect of exemption under Rule 133. ${ }^{40}$ Securities issued in a Rule 133 transaction do not become "free stock" which can be resold without concern as to registration. While securities falling within section 3(a) (2) through section 3(a) (8) of the Act are, due to their intrinsic nature, exempted from registration forever ${ }^{41}$ issues of securities relying upon other statutory exemptions must find another exemption for the secondary distribution..$^{13}$ And it appears that Micro-Moisture Controls could have been decided

35 Securities Act Release No. 3698, CCH FED. SEc. L. Rep. I 76,409 (1956).

36 Securities Act Release No. 3761, CCH FED. Sec. L. Rep. đf 76,510 (1957).

37148 F. Supp. 558 (S.D.N.Y. 1957).

38 Time magazine reported in its February 23, 1959 issue at page 100 that Micro-Moisture controls stock, originally floated at $\$ 1$ per share, was then selling at $1 / 2$ cent a share.

39148 F. Supp. 558 at 562

40 Purcell, 24 Brookryn L. Rev. 254, 263 (1958).

41 In the Matter of Thompson Ross Securities Co., 6 S.E.C. 1111, 1118 (1940). See also H.R. Rep. No. 85, 73d Cong., 1st Sess. 14 (1933) ; H.R. REP. No. 1838, 73d Cong., 2d Sess. 40 (1933).

42 There is a sharp dichotomy between securities exempted under $\$ 3(a)$ (2) through $\S 3(a)(8)$ and those exempted under $\S 3(a)(9)$ through $\S 3(a)(11)$. The securities included in the former group can generally be classed as exempt because of their intrinsic nature, while securities falling within the latter category are exempt because the transaction in which they are issued does not in itself present a situation in which the securities will be publicly distributed. The exemption by $\S 4(1)$ of transactions not involving a public offering is akin to the latter category, and logically, the exemption of Rule 133 is within the same class. However, when securities considered exempt hecause there is no public offering are thereafter sold to the public, the mappropriateness of continuing the exemption for this secondary distribution is evident from a statement of the proposition. A definitive study of the exemption clauses of the Act by two men who have served as General Counsel to the Commission is found in Throop and Lane, Some Problems of Exemption Under the Sectorities Act of 1933, 4 LAw \& ConTEMr. Prob. 89 (1937).

As used herein "secondary distribution" denotes any sale subsequent to the initial issue. 
on the narrow ground that the definition of "issuer," made in section 2(11), as one in control of the issuer removed any reliance on section 4(1) for an exemption of the secondary distribution. Yet, the court's reference to the inapplicability of Rule 133 when a plan exists to sell to the public the stock issued during a reorganization suggests a broad basis-good faith reliance--for restriction of the no-sale theory itself. Since the exemption offered under Rule 133 is self-determining, such a limitation seems only a logical reading of the intent of the statute. And in 1957, in the case of In re Great Sreet Grass Oils, Ltd. and Kroy Oils, Ltd.,43 the Coinmision took the opportunity to solidify the suggestion made in Micro-Moisture Controls of a good faith restriction on the no-sale rule.

The specific facts of Great Sweet Grass-Kroy Oils have been recited at length elsewhere. ${ }^{44}$ Basically, the case involved the use of a series of mergers of controlled corporations to issue quantities of shares of Great Sweet Grass and Kroy, Canadian corporations listed on the American Stock Exchange. Through the use of dummy slareholders, "boiler rooms," Liechtenstein Trusts, and some favorable comment from security analysts, more than $\$ 13,000,000$ worth of shares was sold, mainly to American investors. At most, the value of the assets represented by the shares was $\$ 4,000,000$. When the SEC brought proceedings for delisting under section 19(a) (2) of the Exchange Act, ${ }^{45}$ Sweet Grass and Kroy defended on the basis that the merger transactions fell within the literal wording of Rule 133 and that registration was not required. ${ }^{46}$ In rejecting any defense based upon the no-sale theory the Commission stated:

The theory of Rule 133 is that no sale to stockholders is involyed where the vote of stockholders as a group authorizes a corporate act such as a transfer of assets for stock of another corporation, a merger or a consolidation because there is not present the element of individual consent ordinarily required for a 'sale' in the contractual sense. However, this does not mean that the stock issued under such a plan is 'free' stock which need not be registered insofar as subsequent sales are concerned. Unless the Securities Act provides an exemption for the subsequent sale of such non-registered stock, registration would be required. Of course, subsequent casual sales of such stock by non-controlling stockholders which follow the normal pattern of trading in the stock would be deemed exempt from the provisions of Section 5 of that Act as transactions not involving an issuer, underwriter or dealer under the first clauses of Section 4(1) of the Securities Act. However, if the issuer or persons acting on its behalf participate in the arrangements for a distribution to the public of any stock issued to stockholders or have knowledge of a plan of distribution in connection with the transaction, a Section 4(1) exemption would not be available since an underwriting within the meaning of the statute would be involved.

Where there is a pre-existing plan, as in this case, to use stockholders merely as a conduit for distributing a substantial amount of securities to the public, Rule 133 can not be relied upon by the issuer. . . , Rule 133 is not applicable to an 'exchange' of assets for stock which is 'but a step in the major activity of selling stock.' [Quote from Micro-Moisture]. Sweet Grass and Kroy are chargeable with knowledge of the plan of distribution and such knowledge required each company to register the securities if it wished to avoid violation of Section 5 of the Securities Act. In any event, where the persons negotiating an exchange, merger or similar transaction have sufficient con-

\section{S.E.C. 683 (1957).}

44 See Klaw, The Great Sweet Grass Swindle, Fortune, Aug. 1957, p.134; Purcell, 24 BrookIYN L. Rev. 254, 264 (1958).

45 A major problem in administering Rule 133 and other "self-determining exemptions" of the Securities Act is the belated closing of the barn door approach that such remedies as delisting afford.

46 There is substantial evidence indicating that the scheme of distribution was directed and enjoyed by a single person who was in control of Great Sweet Grass and Kroy and of the merged corporations 
trol of the voting stock to make a vote of stockholders a mere formality, Rule 133 does not apply. In such case the transaction is not corporate action in a real sense, but rather is action reflecting the consent of the persons in control, and consequently results in a 'sale' as to them. Therefore, if an exemption from registration is available it must be found in the statute and can not be based on Rule 133.47

This statement defined three glosses to the no-sale theory: (1) inapplicability of an exemption under section 4(1) for the secondary distribution when those in control of the surviving corporation take stock issued during a reorganization with the intent of making a public distribution; (2) inapplicability of an exemption for the primary distribution under Rule 133 when there is a plan to use recipient stockholders as a conduit through which to make a public distribution; ${ }^{48}$ and (3) inapplicability of an exemption for the primary distribution under Rule 133 when the deal is negotiated by those in control. ${ }^{49}$ The decision appears to follow the suggestion of Micro-Moisture Controls that there is a good faith limitation on the use of Rule 133, and here extends that limitation to invalidate the original transaction. Following these precedents three recent rulings of the Commission, only one of which has been publicly announced, indicate that there will be a concerted program to tighten administration of the Act.

On October $10,1957^{50}$ the Commission ruled that if a substantial shareliolder of a company which will disappear after merger takes securities issued in the reorganization with intent to distribute them to the public, even though he has actively opposed the merger, he must register the secondary distribution under section 5 of the Act. The merger transaction itself would, however, be exempted under Rule 133. This ruling indicates that a controlling or substantial shareholder of a constituent corporation who takes stock issued in a reorganization with intent to make a public distribution must comply with section 5 of the Act when commencing the public sale.

Apparently illustrating this same rule, the Commission held in one of the unannounced cases ${ }^{51}$ that although a contemplated transaction in which a forty per cent family-held interest in a corporation transferring its assets in return for stock held a veto power over the transaction would escape registration under Rule 133, registration would be required before the veto holding block could commence a subsequent distribution of the acquired sliares.

The other case involved a contemplated consolidation of two companies. About nine stockholders of the corporation acquiring stock in the deal had participated in the reorganization negotiations by reason of their positions as officers and directors. The holdings of some of these persons were substantial, but no one person or closely counected group of persons held sufficient shares to give such person or group a

4737 S.E.C. $683,690-91$ (1957).

48 The conduit transaction limitation is applicable when the issuer or persons acting on its behalf participate in arrangements for a distribution to the public of securities issued in a merger or other corporate reorganization or have knowledge of a plan of distribution by, or concerted action on the part of, the recipient shareholders to effect a public distribution.

40 The theoretical basis for this negotiated transaction limitation is that when the vote of the stockholders is a mere formality, the transaction is not "corporate action" in a real sense, but rather is action reflecting the consent of the people in control.

50 Securities Act Release No. 3846, CCH FED. SEC. L. REP. $\llbracket 76,544$ (1957).

51 Report of these rulings is found in Purcell, 24 BrookLyN L. REv. 276 (1958). The transaction involved Lewin-Mathes Company and Cerro de Pasco Corporation and was originally publicized in a talk by Arthur H. Dean at the New York City Bar Association on "Mergers, Consolidations and the SEC With Particular Emphasis on Rule 133 and Section 3(a)9 (sic) of the Securities Act of 1933" p.16 (January 14, 1958). 
veto power over the transaction. The SEC staff concluded that, applying the "negotiated transaction" doctrine, those shareholders who had participated in the negotiations as officers and directors could not distribute their newly acquired shares without registration.

None of these rulings applied the "negotiated transactions" doctrine to the original transaction. It might be argued that since these rulings affected contenplated rather than accomplished transactions, the negotiated aspect of the transaction will not overcome a general presumption of good faith when there is no evidence of a plan of secondary distribution. But, when such a plan is revealed by the facts, as in Great Sweet Grass-Kroy Oils, the original transaction will be struck down on the basis that there was no good faith reliance on Rule 133. Such a rule may be open to criticism as too evanescent to allow proper planning, and it was possibly in recoguition of the uncertainty resulting from the cases and ruhings just discussed that the proposed revision to Rule 133 was offered.

\section{THE Proposed Revision to RuLe 133}

\section{Rationale and operation}

The proposed rule retains the basic no-sale theory, but as an administrative ruling rather than as a rule of law. ${ }^{52}$ Corporate reorganizations covered by the rule will still be considered as not involving "sales" to shareholders receiving securities; however, the rule attempts to stop misuse of the doctrine by focusing on attempts to make a public secondary distribution.

The proposal first provides that anyone who, with a view to distributing securiites issued during a Rule 133 transaction and acting in concert with the issuer or persons controlling the issuer or with persons acting as underwriter for the user, purchases securities exempted under Rule 133 from an acquiring shareholder or sells or offers to sell on behalf of such shareholder is deemed to be a statutory underwriter.$^{53}$ Any distribution by such person will be subject to the registration and prospectus requirements of section 5 . This provision seems intended to reach all possibilities of controlling parties effecting a secondary distribution through dummy shareholders or through persons buying from any shareholders.

'The second specific attack made by the proposed rule is'designed to cover situations in which persons in control of a constituent corporation become minority

52 The Commission bases the proposed revision on a series of conclusions reached by its staff. Briefly summarized they are:

(1) Rule 133 transactions do involvé a "sale within the meaning of $\S 2(3)$ of the Securities Act.

(2) The SEC has authority to promulgate rules which have the effect of declaring that Rule 133 transactions are not "sales" when the Commission concludes that the procedural and liability provisions of the Act would not operate reasonably in such transactions.

(3) In the light of the operation of the procedural and liability provisions of the Act, Rule 133 represents a reasonable interpretation of the $A c t$.

(4) A stockholder acquiring a new security in a transaction falling within Rule 133 has purchased that security from an issuer within the meaning of the Act, and accordingly certain stockholders may be held to be underwrilers if they acquire the security with a view to distribution.

63 This ruling appears consonant with congressional intent. The 1933 House report stated: "The term is defined broadly enough to include not only an ordinary underwriter, who for a commission promises to see that an issue is disposed of at a certain price, but also includes as an underwriter the person who purchases an issue outright wilh the idea of selling that issue to tho public. H.R. REP. No. 85, 73d Cong., 1st Sess. 13 (1933). 
shareholders following a reorganization and then proceed to dispose of their holdings to the public. This situation occurs frequently and has proven difficult to handle under the present Rule 133 since the distributing parties are not in control of the "issuer" and can claim an exemption under section 4(1). Recent decisions and rulings of the SEC, discussed above, were designed to close this loophole. Proposed Rule 133 provides that "any constituent corporation or any person who controls, is controlled by or is under common control with a constituent corporation at the time any Rule 133 transaction ... is submitted to a vote of the shareholders of such corporation who acquires securities of the issuer in counection with such transaction with a view to the distribution thereof," tory underwriter. The proposal then proceeds to exempt sales which might fall within the terms of these proscriptions but which do not involve a public distribution in quantity. ${ }^{65}$

The force of the proposal focuses on the secondary distribution. But it must be remembered that there is nothing in the proposal reversing the Commission's decision in Great Sweet Grass-Kroy Oils, Ltd., and the "negotiated" and "conduit" transaction doctrines can still be invoked when applicable. In fact, the statement of the Commission accompanying the issuance of the proposed rule states that participation by the issuer in a plan of resales by stockholders will require registration by the issuer. ${ }^{5 B}$

Before summarizing the present status of the no-sale rule it appears profitable to investigate the scope of three key phrases used in the proposed rule: "purchase" - "with a view to distribution"-and "control."

The term "purchase" is considered by the SEC staff to include the acquisition of securities in a Rule 133 reorganization. ${ }^{57}$ This conclusion is a logical consequence of the decision that a sale is involved in a Rule 133 reorganization. And the interpretation is consonant with decisions as to the applicability of "purchase" to reorganizations under other statutes administered by the SEC. ${ }^{58}$

The phrase "with a view to distribution" has been construed by the Commission in cases involving secondary distributions of securities exempted from registration under section 4(1). In a series of recent cases involving the 1955-56 convertible debenture financing of the Crowell-Collier Publishing Company, ${ }^{59}$ the Commission has had occasion to consider the confines of the exception made for private offerings, or "purchases for investment and not for resale," the converse of "with a view to distribution." The test adopted in the Crowell-Collier financing cases appears to be based on a reasonable man's interpretation of the purchaser's intent. The most significant factor in such a determination will be the volume of actual resales. The time between purchase and sale, the speculative nature of the securities, the character of the business enterprise involved, and any actual evidence

54 Proposed Rule 133(c), Securities Act Release 3965, CCH FEd. SEc. L. REP. II 76,609, 4133-2 (1958).

65 These provisions are found in Proposed Rule 133(d), and, due to their self-explanatory nature are not further discussed.

56 Securities Act Release No. 3965, CCH Fed. SEc. L. REP. I 76,609 (1958) (Conclusion IV).

57 See note 52 supra.

58 Along with the proposal to revise Rule 133 the SEC staff is preparing a special form for use in the registration of securities in corporate transactions and events which do not meet the no-sale test. This new form would permit the use of a prospectus containing information of the sort now required to be included in a proxy statement under section 14 of the Exchange Act.

59 In the Matter of Eliliott \& Co., CCH FED. SEc. L. REP. II 76,583 (1958); In the Matter of Gilligan, Will \& Co., CCH FED. SEC. L. REP. I 76,584 (1958); In the Matter of Dempsey \& Co., CCH FED. SEC. L. REP. \76,585 (1958). 
of preconceived intent to resell the securities will also be considered. Of major importance in this regard is the long established view of the Commission that since exemptions from the general policy of the Securities Act requiring registration must be strictly construed against the claimant of such an exemption, the burden of proof is on the person seeking to establish the exemption. ${ }^{60}$ Obviously, when a public distribution has in fact been made, the burden will be onerous indeed.

The term "control" is defined by Rule 405 as, "the possession, direct or indirect, of the power to direct or cause the direction of the management and policies of a person, whether through the ownership of voting securities, by contract, or otherwise." 61 This extremely broad definition apparently was intended to allow the Commission to cut through any system of interlocking ownership in order to ascertain the person or group which has actual control. ${ }^{22} \mathrm{~A}$ series of SEC decisions has given the term a sweeping definition. The SEC's views are well expressed in In the Matter of Thompson-Ross Securities:

The question of control is a factual question. 'Control' is not synonomous with the ownership of 51 percent of the voting stock of a corporation. Where power exists to direct the management and policies of a corporation, 'control' within the uneaning of Section 2(11) exists even though the persons who possess that power do not own a majority of the corporation's voting stock. . $^{\text {a }}$

It appears that the use of these terms in Proposed Rule 133 was intended to incorporate their established meaning in practice before the Commission, and it is believed that the definitions noted above will be read into Proposed Rule 133.

\section{The no-sale rule in summary}

The effect of Proposed Rule 133 is to supplement the interpretations previously given to Rule 133. Accordingly, the established SEC positions on the applicability of the no-sale theory, now more properly the no-sale rule, retain their vitality. Rather than recounting these glosses it seems more profitable to examine briefly the reach of the restriction on the use of Rule 133 which will be effected if the current proposals are adopted.

Persons who remain in control of a surviving or new corporation which has issued securities during a reorganization are themselves restricted from making a public distribution of securities received in the transaction since there is no available exemption under section 4(1) for a secondary distribution. Nor does one who purchases securities from such controlling individuals with a view to distribution to the public qualify under section $4(1)$. When a plan exists to use Rule 133 as a conduit to a public distribution, or where the reorganization is a "negotiated transaction," the reorganization transaction itself will not qualify under Rule 133.

Persons who control a corporation which disappears during the transaction and become minority shareholders as a result of the transaction are constrained from making a secondary distribution by the Proposed Rule 133 when they acquire the securities with a view to distribution. All stockholders of the disappearing corporation are, however, allowed to make casual sales, to a specified limit, ${ }^{64}$ as long as

${ }^{0} 0$ See SEC v. Ralston Purina Co., 346 U.S. 119 (1953) ; SEC v. Sunbeam Gold Mines Co,, 95 F.2d 699 (9th Cir. 1938). cases).

6117 C.F.R. $\$ 230.405$ (f) (1949). Sec Loss, Securatres Re(ulation 453 (1951) (collecting

62 See H.R. REp. No. 85, 73d Cong., 1st Sess. 12 (1933).

636 S.E.C. 1111,1119 (1940).

64 See Proposed Rule 133(d). Securities Act Release 3965, CCH FEd. SEc. L. REp. III 76,609, 4133-2 (1958). 
they are not participants, as the term is outlined, ${ }^{65}$ in an attempt to misuse Rule 133. But, when a person working in concert with those in control of the issuer, or with an underwriter of the issuer, purchases securities from a shareholder of a constituent corporation with a view to distribution or sells or offers to sell on behalf of such shareholders, he is declared a statutory underwriter by the Proposed Rule. This last provision overlaps the "conduit" doctrine to some extent, and it appears that the Commission will be able to prosecute for violation of the rules as to the reorganization itself as well as to the secondary distribution.

Assuming adoption of the Proposed Rule, the Commission now appears equipped to reach those, within jurisdictional command ${ }^{86}$ who attempt to use Rule 133 as an umbrella to hide fraudulent public issues. The extent to which the SEC can maintain really effective control of fraudulent securities practices, especially when dealing with "self-determining" exemptions, may be doubted, but it should be noted that the registration and prospectus requirements of the Act are not foolproof devices. ${ }^{67}$ Yet, to the extent that the no-sale theory has afforded a gap in the Commission's prograin of enforcement, the SEC appears to be acting effectively to restore integrity to the registration and prospectus requirements of the Securities Act.

David E. Nelson

65 Ibid.

${ }^{06}$ The promoter of the Great Sweet Grass Swindle is reported resting comfortably in Canada, outside the Commission's reach.

67 The Commission itself has noted the difficulty of effectively protecting investors under the Act's present provisions. See, e.g., 24 SEc. ANN. REp. 1-8 (1958). 